\title{
ПРАКТИЧНА РЕАЛІЗАЦІЯ ПУБЛІЧНОЇ ДИПЛОМАТІЇ КОРОЛІВСТВА НОРВЕГІЇ В КРАЇНАХ АФРИКИ, БЛИЗЬКОГО СХОДУ, АЗЇ, ЦЕНТРАЛЬНОЇ ТА ЛАТИНСЬКОЇ АМЕРИКИ
}

Анотащія: Стаття присвячена висвітленню питання реалізації публічної дипломатії Королівства Норвегії у країнах Африки, Близького Сходу, Азії, Центральної та Латинської Америки. Даний вид дипломатії здійснює Норвезьке агентство з питань співробітництва у галузі розвитку (NORAD), яке було створене ще у 1968 році як Директорат допомоги розвитку та займається розвитком міжнародного співробітництва Норвегії з іншими акторами міжнародної арени. Публічна дипломатія Норвегії, яку реалізує NORAD, провадиться через інструмент допомоги країнам у питаннях освіти громадян, прав людини та належного управління. Значна увага приділяється захисту довкілля, збереженню лісів і питанням клімату.

Ключові слова: публічна дипломатія, інструменти публічної дипломатії, Норвегія, Азія, Африка, Близький Схід, Центральна та Латинська Америка

Сьогодні, аби заявити про себе на міжнародній арені, як традиційні, так і нетрадиційні учасники все частіше звертаються до застосування публічної дипломатії. Серед таких є й Королівство Норвегія, яке часто називають «іншою країною» або «невидимою країною». Багато в чому це пов'язано з тим, що ця країна не є членом ЄC, або тому, що Норвегія є однією з небагатьох країн, які не зазнали впливу фінансової кризи останніх років, як інші західні країни. Окрім цього, її часто розглядають як частину цілого, поряд з іншими скандинавськими країнами у питанні міжнародного культурного визнання. Тому, щоб довести свою унікальність, впливовість і важливість Королівство Норвегія починає активно реалізовувати публічну дипломатію за допомогою дій, а не мовлення.

Аналізуючи стан наукової розробки даної тематики, варто відмітити, що на сьогоднішній день ми маємо значну кількість наукових статей і монографічних досліджень як серед вітчизняних, так і зарубіжних дослідників щодо загальної концепції «публічної дипломатії» (Дж. Най ${ }^{85}$, Н. Цвєткова ${ }^{86}$, Н. Іванова ${ }^{87}$ й ін.). Однак тематика реалізації публіч-

\footnotetext{
" Вовчук Людмила Анатоліївна - кандидат історичних наук, доцент кафедри міжнародних відносин та зовнішньої політики Чорноморського національного університету імені Петра Могили (м. Миколаїв);

ORCID: https://orcid.org/0000-0002-8324-5235; e-mail: luda_vovchuk@ukr.net

Белінська Тетяна Андріївна - магістр з міжнародних відносин Universite Libre de Bruxelles (м. Брюссель, Бельгія); ORCID: https://orcid.org/0000-0001-9067-5359; e-mail: t.belinskaya.a@gmail.com

${ }^{85}$ Nye Joseph S. Jr. Bound to Lead: The Changing Nature of American Power. New York: Basic Books. 1991. 336 p.

${ }^{86}$ Цветкова Н.А. Публичная дипломатия США: теории и концепции // Исторические, философские, политические и юридические науки, культурология и искусствоведение. Вопросы теории и практики. Тамбов: Грамота, 2015. № 4 (54). Ч. І. С. 186-189.
} 
ної дипломатії Королівства Норвегії в країнах Африки, Близького Сходу, Азії, Центральної та Латинської Америки практично не досліджена і представлена, в основному, поодинокими монографічними дослідженнями та науковими статтями норвезьких дослідників, серед яких варто виокремити роботи Дж. Стора, Дж. Веа, Алана К. Хенріксона ${ }^{88}$, в яких вчені висвітлюють шляхи формування публічної дипломатії Норвегії та вказують на сильні і слабкі сторони стратегії публічної дипломатії цієї країни.

Певний інтерес до цієї тематики простежується і серед дослідників Східної та Західної Європи. Так, румунський дослідник Стефан Теодор Попа безпосередньо у своїй науковій праці «Культурна та публічна дипломатія Норвегії» ${ }^{89}$ розкриває особливості розвитку та реалізації публічної дипломатії цієї країни.

Вітчизняні ж дослідники практично не займаються розробкою даної теми, акцентуючи увагу на країнах ЄC i Північної Америки. Наразі можна вказати праці М. Трофименка ${ }^{90}$, в яких автор представив аналіз особливостей публічної дипломатії Королівства Норвегія через дослідження їі стратегії, механізмів та інструментів реалізації. А також матеріали виступів Т. Белінської ${ }^{91}$, в яких молода дослідниця безпосередньо висвітлює становлення публічної дипломатії Норвегії та її реалізацію у країнах Азії та Африки.

У Норвегії створено низку інституцій, які займаються реалізацією напрямів публічної дипломатії країни. Так, до цієї системи входить Міністерство закордонних справ, яке є головним гравцем у координації діяльності публічної дипломатії, організації «Visit Norway», «Innovation Norway» або «NORAD» (агентство з розвитку), які також відіграють вирішальну роль у просуванні країни на міжнародній арені.

Саме NORAD або Норвезьке агентство з питань співробітництва в галузі розвитку, яке було створене ще в 1968 р. як Директорат допомоги розвитку, і займається розвитком міжнародного співробітництва. Тому публічна дипломатія Норвегії, яку реалізує NORAD, провадиться через інструменти допомоги країнам у питаннях освіти громадян, прав лю-

\footnotetext{
${ }^{87}$ Иванова Н. Публічна дипломатія як ефективний механізм зовнішньої політики держави // Вісник Харківського національного університету імені В.Н. Каразіна. Серія «Питання політології». 2018. № 32. С. 122-127.

${ }^{88}$ Alan K. Henrikson Niche Diplomacy in the World Public Arena: the Global 'Corners' of Canada and Norway // The New Public Diplomacy. P. 67-87. URL: https://link.springer.com/chapter/10.1057/9780230554931_4; Støre J.G. Utenrikspolitisk grunntone // Morgenbladet. $11^{\text {th }}$ of September 2009. URL: https://morgenbladet.no/debatt/2009/utenrikspolitisk_grunntone; Vea J. Omdømmeutvalgets Sluttrapport: Nyskapende i samspill med naturen, Oslo. https://www.regjeringen.no/globalassets/upload/kilde/ud/bro/2006/0049/ddd/pdfv/275674nyskapende_i_samspill_internett.pdf

${ }^{89}$ Popa T. Norway's Public and Cultural Diplomacy // Journal of Global Politics and Current Diplomacy. 2015. № 3. P. 35-49.

${ }^{90}$ Трофименко М.В. Публічна дипломатія Норвегії // Вісник Маріупольського державного університету. Серія: Iсторія. Політологія. 2016. Вип. 16. С. 329-336. URL: http://nbuv.gov.ua/UJRN/Vmdu_ip_2016_16_43; Трофименко М.В. Публічна дипломатія королівства Норвегія // Вісник Маріупольського державного університету. Серія: Історія. Політологія / за заг. ред. К.В. Балабанова. 2017. Вип. 18. С. 381-389.

${ }^{91}$ Белінська Т. Становлення публічної дипломатії Норвегії // «Могилянські читання - 2019». Всеукраїнська науково-методична конференція. «Досвід та тенденції розвитку суспільства в Україні: глобальний, національний та регіональний аспекти»: тези. Миколаїв: Вид-во ЧНУ імені Петра Могили, 2019. С. 50-52; Белінська Т. Практика реалізації публічної дипломатії Королівства Норвегія в країнах Азії та Африки у XXI ст.. // Аркасівські читання: матеріали Х Міжнародної наукової конференції (травень 2020 р.). Миколаїв: МНУ імені В.0. Сухомлинського, 2020. С. 32-35.
} 
дини та належного управління. Низка країн Африки, Азії та Океанії, Близького Сходу та Латинської Америки отримують організаційну та фінансову допомогу від Норвегії в питаннях освіти, забезпечення рівних прав громадян і демократичних цінностей.

Так, з 2011 р. Норвегія зробила свій внесок у багатосторонній донорський фонд «Демократичне управління» в Уганді, який підтримує демократичний розвиток, права людини, мир, судовий сектор та ініціативи щодо зміцнення зусиль громадянського суспільства щодо привернення уваги до фінансових порушень та неефективного використання державних ресурсів ${ }^{92}$.

Наприкінці 2014 р. цей фонд працював з 81 партнером, переважно з громадянського суспільства, а також 3 державними установами, такими як Угандійська комісія з прав людини та парламентом.

У 2014 р. була надана допомога загальною сумою 80 тис. норвезьких крон 3 метою розв'язання земельних спорів. Приблизно 500 тис. жінок і чоловіків отримали соціальну освіту. Окрім того, було покращено звітність про корупцію. Збільшилася участь жінок у місцевій демократії, посилилися знання людей щодо обов'язків держави 3 прав людини ${ }^{93}$.

У тому ж 2014 р. донорський фонд «Демократичне управління» в Уганді отримав ще 37 млн. норвезьких крон для вирішення питання щодо прав сексуальних меншин відповідно до міжнародного профілю Норвегії та визначення пріоритетності цього питання, оскільки у самій Уганді ця тема досить складна. Тому Норвегія активно підтримує місцеві зусилля щодо вирішення цього питання.

Також в Уганді реалізується Програма фінансового менеджменту та підзвітності (FINMAP), яка спрямована на реформи у сфері управління державними фінансами. Програма фінансується Норвегією, Ірландією, Швецією, ЄС, Департаментом міжнародного розвитку (DFID) та Угандійською державою. Іноземні донори фінансували 54\% витрат у 2013/14 рр., при цьому внесок Норвегії становив 28\% ${ }^{94}$.

Окрім Уганди, Норвегія співпрацює і з Ліберією. Так, у 2014 р. Норвегія уклала договір про наміри з країною щодо лісової програми REDD+. Ліберія є найбільшою лісовою країною у Західній Африці і більше 30\% території суші покрита тропічними лісами. Після закінчення громадянської війни 2003 р. та скасування міжнародних санкцій проти країни збільшився тиск на лісові ресурси, особливо від іноземних лісопромислових підприємств і плантаційної промисловості. Тому постала проблема скорочення викидів парникових газів внаслідок вирубки лісів і деградації лісів (REDD+) у Ліберії.

Норвезька ініціатива з клімату та лісу підтримує REDD+ в Ліберії через екологічну організацію Fauna \& Flora International й інші міжнародні та місцеві неурядові організації. Мета полягає у тому, щоб підвищити знання REDD+ і про те, як місцеві громади можуть отримати вигоду від довгострокового управління лісами.

Через низку курсів і семінарів, а також національну інформаційну кампанію на радіо та телебаченні, організація, у певній мірі, сприяла підвищенню рівня знань про клімат

\footnotetext{
${ }^{92}$ Popa S.T. Norway's Public and Cultural Diplomacy // Journal of Global Politics and Current Diplomacy. 2015. № 3. P. 35.

${ }^{93}$ Norwegian development cooperation with a selected number of partner countries // Norwegian Agency for Development Cooperation: official page. URL: https://norad.no/en/front/countries/

${ }^{94}$ Ibidem.
} 
і ліси як у громадській думці, так і серед політиків та інших осіб, які приймають рішення. Зусилля проекту також сприяли формуванню національних рекомендацій щодо більш екологічно чистого виробництва пальмової олії - галузі, яка часто є причиною вирубки лісів. Згідно з попередньою оцінкою, відсутність знань більше не є найбільшою перешкодою для скорочення вирубки лісів у Ліберії.

Також Норвегія приділяє увагу співпраці з Мадагаскаром, з яким зміцнила дипломатичні відносини у 2004 р., створивши власне посольство в Антананаріву. У тому ж році Мадагаскар отримав статус країни-партнера Норвегії, якому остання надала значну фінансову допомогу у питанні розвитку освіти та належного управління.

32008 р. Норвегія надала щорічну підтримку музичному фестивалі «Madajazzcar», одному з небагатьох національних фестивалів Мадагаскару. Ця підтримка була припинена лише у 2017 р., і підтримка сектору культури зараз спрямовується до національної платформи для просування та розвитку сучасних виконавських мистецтв, Асоціації культури.

Однак, у зв'язку з масовими заворушеннями у 2009 р. (боротьба за владу між діючим президентом і мером Антананаріву) Норвегія, як і білышість іноземних країн, заморозила свою двосторонню допомогу Мадагаскару. Після перевороту норвезька підтримка освіти була спрямована через організації ООН. Найбільш важливою серед них була ЮНІСЕФ, яка взяла на себе відповідальність за утримання освіти, а Міжнародна організація праці (МОП) відповідала за будівництво нових шкільних будівель і Всесвітню продовольчу програму для шкільних їдалень.

Норвегія зосередила свої зусилля на трьох південних регіонах країни та допомогла зберегти там можливості для навчання, незважаючи на політичну кризу та міжнародну ізоляцію. У 2015 р. було підписано нову трирічну угоду з ЮНІСЕФ для продовження підтримки від Норвегії ${ }^{95}$.

У сфері охорони здоров'я Норвегія підтримала організацію допомоги «Mercy Ships» у 2016 р. $з$ одноразовою виплатою. Організація співпрацювала з університетською лікарнею міста Тоамасіна з підготовки фахівців, реконструкції водяних, електричних і санітарних приміщень у лікарні, а також придбання обладнання для операційної.

Через Програму розвитку Організації Об’єднаних Націй (ПРООН) Норвегія надала підтримку здійсненню виборів у 2013 р., що становила понад 7 млн. норвезьких крон. У 2015 р. Норвегія уклала трирічну угоду з ЮНІДО з фінансуванням, яке було спрямоване на виділення грантів для жінок.

Основною метою присутності Норвегії у Судані є сприяння виконанню угод з метою досягнення миру в країні та миру між Суданом і Південним Суданом. Основними каналами допомоги у розвитку є система ООН і деякі норвезькі та міжнародні організації 3 надання допомоги. Загальна сума допомоги Норвегії Судану в 2017 р. склала близько 107,9 млн. норвезьких крон. Це включає внески в операції з підтримки миру та гуманітарну допомогу, що здійснюється Міністерством закордонних справ Норвегії ${ }^{96}$.

Приблизно одна третина підтримки Судану набуває форми гуманітарної допомоги в районах, що постраждали від конфлікту. Особливо це стосується Південного Кордофа-

\footnotetext{
${ }^{95}$ Popa T. Norway's Public and Cultural Diplomacy... P. 43.

${ }^{96}$ Norwegian development cooperation with a selected number of partner countries...
} 
на, Блакитного Нілу та Дарфура. Норвегія підтримує зусилля, спрямовані на забезпечення миру та стабільності у Дарфурі. Фонд добровільності та стабільності Дарфуру управляється ПРООН за підтримки Норвегії й інших країн. Програма допомогла вирішити конфлікти без застосування насильства. Вона також сприяла розбудові відносин між місцевими громадами, що, тим самим, запобігає виникненню конфлікту в майбутньому. Фонд є одним 3 декількох заходів, які допомагають пом'якшити конфлікт, коли його рівень посилився $^{97}$.

Досить серйозною є й допомога Норвегії країнам Близького Сходу. Так, починаючи з 1993 р., Норвегія виступила посередницею у конфлікті між Ізраїлем і Палестиною, тим самим сприяючи підтримці миру. Норвезькі політики, члени Лейбористської партії та релігійні кола завжди підтримували тісні зв'язки зі своїми ізраїльськими колегами. А наукові дослідження призвели до нових норвезько-ізраїльських зв'язків.

Але, не дивлячись на це, Норвегія не залишилася осторонь і щодо Палестини, визначивши у 2014 р. три пріоритетні напрями їх співпраці: бюджетна підтримка, реконструкція Гази й освіта. Оскільки загальна криза ліквідності, що впливає на Палестину, є загрозою для державотворення, норвезька бюджетна підтримка вважається вирішальним внеском у підтримку цієї роботи. Бюджетна підтримка фінансувала поточні видатки державного бюджету, включаючи зарплати. Як голова групи координаторів донорів AHLC, Норвегія переслідувала свою особливу роль у сфері координації міжнародних донорів.

у 2014 р. Норвегія надала 269 млн. норвезьких крон бюджетної підтримки, яка спрямувалася через багатосторонній донорський фонд Світового банку. Метою є державотворення та допомога у збереженні важливих державних установ у Палестині. Бюджетна підтримка йшла й на фінансування виплат зарплати працівникам. Загалом Палестина отримала близько 1 млрд. дол. США у вигляді бюджетної підтримки з різних країн.

У результаті такої допомоги, Палестині вдалося досягти певного прогресу. Так, країна здійснила деякі правові реформи для закриття податкових прогалин, але, наприклад, їй не вдалося досягти цілей бюджету для зростання заробітної плати у державному сектоpi, платежів за електроенергію Ізраїлю або медичних рефералів ${ }^{98}$.

Взагалі такі організації як «Норвезька народна допомога», «Норвезька церковна допомога», «Норвезька рада біженців», «Норвезький комітет допомоги» (NORWAC) та «Врятуй дітей» мають широкі програми в Палестині у сфері освіти, охорони здоров'я, сільського господарства, прав людини та захисту. Ці програми реалізуються на Західному березі, включаючи Східний Єрусалим і Сектор Газа. Всі ці організації відіграли ключову роль у достроковому відновленні роботи у Газі відразу після війни, а також визначили й охопили сфери, які великі організації ОOH не можуть охопити. Наприклад, NORWAC організувала надання дуже необхідних ліків і медичного обладнання для лікарні Shifa в Газі під час війни, а також лікування травм після війни у співпраці з лікарнею Shifa i лікарнею Makassed в Єрусалимі. Норвезька рада біженців забезпечила гарну координацію сектору притулку в Газі з часів війни.

\footnotetext{
${ }^{97}$ Белінська T. Практика реалізації публічної дипломатії Королівства Норвегія в країнах Азії та Африки у XXI ст.... С. 32-33.

${ }^{98}$ Norwegian development cooperation with a selected number of partner countries...
} 
Окрім вище вказаних країн, Норвегія є шостим найбільшим гуманітарним донором Сирії та її сусідам, і на сьогодні вона надала 1,3 млрд. норвезьких крон гуманітарної допомоги 3 початку війни (2011р.). Норвегія також зробила свій внесок у знищення хімічної зброї у Сирії.

У 2014 р. норвезький уряд надав 460 млн. норвезьких крон жертвам конфлікту в Сирії. Близько половини цього внеску буде спрямовано на гуманітарні ініціативи всередині країни. Інша половина була надана сирійським біженцям у сусідні країни.

Через NORAD Норвегія підтримує гуманітарні зусилля Організації Об'єднаних Націй, Міжнародного Червоного Хреста та добровільних організацій, які працюють всередині Сирії. NORAD забезпечував продовольством, житлом і водопостачанням потерпілих, докладав зусиль у побудові санітарно-гігієнічних об'єктів ${ }^{99}$.

Враховуючи той факт, що конфлікт у Сирії призвів до того, що, по-перше, 1,3 млн. сирійських дітей стали біженцями у сусідніх країнах, а, по-друге, загалом 2,8 млн. дітей у Сирії не можуть відвідувати школу, Норвегія прийняла рішення сприяти вирішенню освітнього питання. У результаті, організація «Врятуй дітей» відновила 39 навчальних закладів на півночі Сирії, для чого набрано майже 800 волонтерів, у тому числі 650 вчителів і 75 директорів. Приблизно 260 вчителів пройшли навчання щодо методів викладання, навичок надання психологічної підтримки та навчання студентів основам здоров'я та гігієни в екстремальних умовах. Також вчителів навчали, як дітям краще захищатись від експлуатації та домагань і як втілити у навчальний процес вивчення позитивних, ненасильницьких дисциплін у школах.

Після відновлення роботи навчальних закладів і нарощування потенціалу вчителів та персоналу в школах, організація «Врятуй дітей» ініціювала активну кампанію «Назад до школи». До кінця 2013 р. проект «Зберегти дітей» охопив близько 14 тис. дітей молодшого шкільного віку ${ }^{100}$.

Освітня діяльність також є важливою частиною роботи Норвезької ради біженців як в Сирії, так і в сусідніх країнах - Йорданії, Лівані й Іраку. Мета полягає у тому, щоб забезпечити освіту в безпечному середовищі для якомога більшої кількості дітей. Заходи включають домовленості про те, щоб сирійські діти могли ходити до школи в приймаючих країнах, додаткові уроки, матеріальну підтримку студентів і викладачів, реабілітацію шкіл та інші ініціативи ${ }^{101}$.

Саме за підтримки Норвегії та ї̈ співробітників Верховного комісару ООН у справах біженців, ЮНІСЕФ, організації «Врятуй дітей», іншим міжнародним організаціям та місцевим учасникам вдалося дещо нормалізувати ситуацію щодо даного питання.

Також Норвегія співпрацює з ліванськими органами влади у рамках програми «Нафта для розвитку» (OfD), метою якої є забезпечення сталого управління нафтовими ресурсами на користь поточних і майбутніх поколінь. Співробітництво включає надання технічної експертизи на основі уроків, отриманих у Норвегії, особливо стосовно управління та прозорості. У 2014 р. було виділено 4,8 млн. норвезьких крон на даний напрямок. У результаті,

\footnotetext{
${ }^{99}$ Ibidem.

${ }^{100}$ Hør våre stemmer // Redd Barna: official page. URL: https://www.reddbarna.no/redd-barna-blogg/hoer-vaarestemmer

${ }^{101}$ Norwegian development cooperation with a selected number of partner countries...
} 
програма OfD в Лівані допомогла розробити стратегічні та правові рамки для нафтового сектору та розширила компетенції у галузі управління нафтою.

Окрім цього, Норвегія надає Лівану щорічну підтримку проектам у сфері миру та примирення, прав людини та зміцнення культурного сектору, а також захисту жінок i гендерної рівності, що тим самим сприяє розбудові громадянського суспільства Лівану, оскільки основна частина фінансування присвячена місцевим або національним організаціям ${ }^{102}$.

Розглядаючи співпрацю Норвегії з азійськими країнами, варто зазначити, що М’янма є однією з пріоритетних азійських країн, якій Норвегія надає допомогу в питанні управління природними ресурсами, енергетики, навколишнього середовища та клімату. Значний акцент робиться на реалізації питань миру та примирення, політичних та економічних реформах. Так, у 2014 р. сумарна норвезька допомога М'янмі склала приблизно 230 млн. норвезьких крон.

Під час офіційного державного візиту в 2014 р. було підписано Меморандум про взаєморозуміння щодо розвитку співробітництва між країнами. Головною метою якого було сприяти розвитку нафтової промисловості, інституційного співробітництва у галузі гідроенергетики та двостороннього екологічного співробітництва між Норвегією та М'янмою.

У співпраці з іншими донорами Норвегія підтримала зусилля ЮНІСЕФ у сфері базової освіти та розвитку початкових шкіл М'янми. Ця підтримка включає політичні реформи, зміцнення потенціалу на місцевому та національному рівнях і надання послуг у 34 особливо вразливих селищах. Так, починаючи з 2012 р., більш ніж 185 тис. дітей, у рамках програм «Розвитку дітей раннього віку», отримали змогу здобути неформальну базову освіту та навчитися життєвим навичкам. 3 них близько 5 тис. проживають у таборах для внутрішньо переміщених осіб. Всього 900 тис. дітей були забезпечені необхідним шкільним обладнанням ${ }^{103}$.

Треба відзначити, що норвезька співпраця з В'єтнамом у сфері розвитку сягає вже більше 40 років. У період з 1972 по 2013 рік офіційна державна допомога Норвегії В'єтнаму склала понад 2,3 млрд. норвезьких крон. Пріоритетними напрямками норвезької публічної дипломатії у В'єтнамі з 2008 р. стали: клімат, навколишнє середовище та лісове співробітництво; відновлювальна енергія; технічне співробітництво; жінки та гендерна рівність; культура.

Варто зазначити, що Норвегія, окрім прямих грошових дотацій, надає також значні нецільові кошти організаціям ООН, які працюють у В'єтнамі. Низка норвезьких громадських організацій мають присутність у В’єтнамі ${ }^{104}$.

Щодо Центральної Америки, то Норвегія виділила 31,1 млн. крон у 2018 р. на підтримку Нікарагуа. Норвегія уклала чотирирічну угоду про співпрацю 3 підтримки поліції у цій країні, оскільки саме тут поліція має виняткове становище. Вона користується вели-

\footnotetext{
${ }^{102}$ Olje for utvikling // Norwegian Agency for Development Cooperation: official page. URL: https://norad.no/tema/okonomisk-utvikling-og-offentlig-forvaltning/olje-for-utvikling/

${ }^{103}$ Norwegian development cooperation with a selected number of partner countries...

${ }^{104}$ Белінська T. Практика реалізації публічної дипломатії Королівства Норвегія в країнах Азії та Африки у XXI ст.... С. 34.
} 
кою довірою серед населення та значною мірою зуміла здійснити контроль над викликами злочинності та насильства, з якими борються інші країни. Новий проект мав сприяти кращому навчанню в галузі прав людини у поліцейській академії. Це стосувалося, зокрема, й гендерної рівності та запобігання насильству щодо жінок. Важливою частиною проекту стало також запобігання злочинності молоді. Останній внесок Норвегії до Фонду боротьби з корупцією у Нікарагуа був зроблений для реалізації того, що називається «національною стратегією належного управління», яка була розроблена після багаторічної підтримки Норвегії й інших донорів ${ }^{105}$.

Варто відзначити норвезьку допомогу у питанні функціонування малих гідроелектростанцій у Нікарагуа, які надають електроенергію 8262 сім'ям за межами національної електромережі, допомагаючи в цілому 50 тис. особам. У результаті такої допомоги покращився стан життя людей, почав розвиватися малий бізнес, з'явилися освітні вечірні курси, покращився стан освіти у цілому. Окрім Норвегії до цієї допомоги долучилися Швейцарія й ООН (ПРООН).

Норвегія сприяла функціонуванню близько двадцяти центрів для жінок і дітей у Нікарагуа, а також проведенню профілактичної роботи для жінок, які стали жертвами насильства та жорстокого поводження. Разом зі Швейцарією Норвегія також підтримує проект ООН щодо прав жінок, який був розпочатий у 2013 р., оскільки саме тоді значна частина громадянського суспільства виступала проти поправки, яка запровадила обов'язкове посередництво між жертвою та злочинцем у справах про насильство проти жінок.

Протягом трьох років (2010-2012 рр.) Норвегія надала більше 800 млн. норвезьких крон на підтримку Гаїті. Приблизно чверть цієї суми було витрачено на вирішення невідкладних гуманітарних потреб. Інша частина була надана на реалізацію довгострокової реконструкції та розвитку, роблячи акцент на зменшенні вразливості населення до майбутніх природних катастроф.

Велика частка норвезького фінансування Гаїті спочатку була надана через багатосторонній донорський фонд і Фонд реконструкції Гаїті (HRF), співробітництво між гаїтянськими органами влади та міжнародним співтовариством, керованим Світовим банком. Крім того, підтримка Норвегії була розподілена між різними організаціями - ООН, Світовим банком, багатостороннім донорським фондом і регіональними органами влади ${ }^{106}$.

Серед латиноамериканських країн увага Норвегії зосереджена на підтримці громадянського суспільства у Бразилії, де акцент робиться на боротьбі зі злочинністю, пов'язаною з лісами, картографуванні тропічних лісів і забезпеченні використання стабільних сільськогосподарських методів. Фонд Rainforest працює над посиленням прав корінних народів у Бразилії. Метою програми є захист 1,2 млн. квадратних кілометрів тропічних лісів у семи визначених регіонах, територія яких населена 385 різними корінними групами.

Отже, нині Королівство Норвегія залишається активним учасником реалізації своєї публічної дипломатії у країнах Африки, Близького Сходу, Азії, Центральної та Латинської

\footnotetext{
${ }^{105}$ Norwegian development cooperation with a selected number of partner countries... ${ }^{106}$ Ibidem.
} 
Америки. Реалізація відбувається через надання допомоги норвезькими організаціями та за підтримки міжнародних організацій постраждалим громадянам вище вказаних країн. Пріоритет надається освіті, захисту прав жінок, гендерній складовій, поширенню демократичних свобод та ін. Варто зазначити, що ця допомога має реальну позитивну динаміку щодо вирішення тих чи інших питань. Прагнучи, таким чином, створити імідж стабільної, важливої та впливової держави, Норвегія допомагає багатьом країнами вирішити нагальні проблеми і тим самим нормалізувати внутрішню ситуацію.

\section{Liudmyla Vovchuk, Tetiana Belinska}

\section{Practical Implementation of Public Diplomacy of the Kingdom of Norway in the Coun- tries of Africa, Middle East, Asia, Central and Latin American}

Abstract: Today, Norway uses a wide range of tools to implement public diplomacy from official meetings, exhibitions, forums, to the introduction of special projects to promote Norway as a wealthy, social, cultural country that does everything to establish peace around the world. It is the Norwegian Agency for Development Cooperation (NORAD), which was established in 1968 as the Directorate for Development Assistance, and is involved in the development of Norway's international cooperation with other actors in the international arena. A number of countries in Africa, Asia, the Middle East, Central and Latin America receive organizational and financial assistance from Norway in education, equal rights and democratic values. Much attention is paid to the protection and restoration of forests, as well as climate issues.

The first to receive assistance from Norway were African countries: Uganda, Liberia, Sudan, Madagascar. The funds were used to support democratic development, human rights, peace, the judiciary and initiatives to strengthen civil society's efforts to address financial irregularities and inefficient use of public resources to resolve land disputes. In addition, significant Norwegian assistance is aimed at developing the cultural sphere (holding music festivals).

Norway's assistance to the Middle East is also quite serious. Thus, since 1993, Norway has acted as a mediator in the Israeli-Palestinian conflict, thus contributing to the maintenance of peace. Nevertheless, Norway did not stay away from Palestine, identifying in 2014 three priority areas for cooperation: budget support, Gaza reconstruction and education.

Considering Norway's cooperation with Asian countries, it should be noted that Myanmar and Vietnam are one of the priority Asian countries to which Norway provides assistance in the management of natural resources, energy and environment, climate. Significant emphasis is placed on the implementation of peace and reconciliation, political and economic reforms.

Among Latin American countries, Norway's focus is on supporting civil society in Brazil, where the emphasis is on combating forest-related crime, mapping tropical forests and ensuring stable agricultural practices. 
As a result, through the implementation of public diplomacy, Norway has managed not only to create the image of a successful, important and influential country, but also to help address important issues in the above countries.

Keywords: public diplomacy, instruments of public diplomacy, Norway, Asia, Africa, Middle East, Central and Latin America 